\title{
Stickers versus wafers: The value of resource in a public goods game with children
}

Phiética Raíssa Rodrigues da Silva. Universidade Federal do Rio Grande do Norte.

Natalia Andrea Cracciun Boccardi. Universidade Federal do Rio Grande do Norte.

Natalia Bezerra Dutra. Durham University.

Wallisen Tadashi Hattori. Universidade Federal de Uberlândia.

Maria Emília Yamamoto. Universidade Federal do Rio Grande do Norte.

Anuska Irene Alencar. Universidade Federal do Rio Grande do Norte.

\begin{abstract}
We investigated how the type of resource, food (wafer) or non-food (sticker), age and sex influence cooperation in children. 251 children were tested in a public goods game during eight rounds in two experimental conditions: wafer or sticker condition. Wafers were all of the same kind but stickers were varied. The results indicated that 1) older children donated more stickers than younger children, but they did not differ in relation to wafer donations; and 2) sticker donations remained high along the rounds, while wafer donations decreased. We propose that different strategies may be adopted according to the quality, particularly to the diversity of the resource used, and the cost of cooperation may be overcome when it is more advantageous to wait for a future reward.
\end{abstract}

Keywords: behavioral economics; kind of reward; behavioral sciences; evolutionary psychology; game theory; cooperation.

\section{Resumo}

Adesivos versus wafers: O valor do recurso em um jogo de bens públicos com crianças. Investigamos como o tipo de recurso, alimentar (wafer) ou não-alimentar (adesivo), a idade e o sexo influenciam a cooperação em crianças. Foram testadas 251 crianças em um jogo de bens públicos durante oito rodadas, em duas condições experimentais: condições wafer ou adesivo. Os wafers eram todos iguais, mas os adesivos eram variados. Os resultados indicaram que 1) as crianças mais velhas doaram mais adesivos do que as crianças mais jovens, mas elas não diferiram em relação às doações de wafers; e 2) as doações de adesivos mantiveram-se elevadas ao longo das rodadas, enquanto as doações de wafers diminuíram. Propomos que diferentes estratégias podem ser adotadas de acordo com a qualidade, particularmente quanto à diversidade do recurso utilizado, e o custo de cooperar pode ser superado quando é mais vantajoso esperar por uma recompensa.

Palavras-chave: comportamento econômico; tipo de recompensa; psicologia evolucionista; teoria dos jogos; cooperação.

\section{Resumen}

Pegatinas versus obleas: El valor del recurso en un juego de bienes públicos con niños. Investigamos como el tipo de recurso, alimentar (oblea) o no alimentar (pegatina), la edad y el género influyen en la cooperación de los niños. 251 niños fueron investigados en ocho partidos de un juego de bienes públicos, en dos condiciones experimentales: oblea o pegatina. Las obleas eran todas iguales, pero las pegatinas eran variadas. Los resultados indicaron que 1) los niños mayores donaron más pegatinas que los niños más pequeños, pero no difieren con respecto a las donaciones de obleas; y 2) las donaciones de pegatinas se mantuvieron altas durante las rondas, mientras que las donaciones de obleas disminuyeron. Proponemos que diferentes estrategias pueden ser adoptadas de acuerdo con la calidad, particularmente con respecto a la diversidad de los recursos utilizados, y el costo de la cooperación puede ser superado cuando es más ventajoso esperar por una recompensa futura mejor.

Palabras clave: comportamiento económico; tipo de recompensa; la psicología evolutiva; la teoría de los juegos; cooperación. 
Social dilemmas may arise when an individual attempts to maximize his gains by using a resource without contributing to keep it, but if everyone does the same the resources will be extinguished and everyone will be adversely affected (Alencar \& Yamamoto, 2008; Kollock, 1998; Ostrom, 2001). A way to investigate social dilemmas is through economic games, including the public goods game. This game allows the experimenter to simulate a situation where a group invests in a particular resource from which everyone can benefit, even those individuals who do not contribute to the provision of good (Kollock, 1998), which enables the study of cooperation in sizable groups. The term cooperation is used in the economic games literature to indicate a contribution to a partner or a public fund (Kümmerli, Burton-Chellew, Ross-Gillespie, \& West, 2010; Lotz, 2014; Rand, Arbesman, \& Christakis, 2011), and will be used in this paper to refer to that kind of behavior. The term generous will also be used, particularly when referring to sharing.

Cooperation in humans is manifested in early stages of development (Schmidt \& Sommerville, 2011; Vogt, Efferson, Berger, \& Fehr, 2015). However, the literature shows conflicting results about the influence of age. Harbaugh and Krause (2000) investigated the behavior of children with different ages in a public goods game, suggesting that older children are initially more generous than the younger ones, but they quickly learn to cheat along the interactions. House, Henrich, Brosnan and Silk (2012) tested the behavior of children between 3 and 8 years old in a face-to-face task. In the test, a child shared the resource (food) between herself and another child. The results showed that children younger than 6 years old were more generous than older ones, but that prosocial behavior increased with age after this period. Zarbatany, Hartmann and Gelfand (1985) also have investigated the behavior of children from six to 10 years. Their results suggest that older children were more generous than younger ones only under the experimenter surveillance. Blake, McAuliffe and Warneken, (2014) suggested that young children understand the principles of fairness, but do not follow them and will only do so when they start to worry about their reputation, when 8 years and older. Otherwise, older children's behavior did not differ from the behavior of the younger ones.
The literature on sex differences also reports mixed results (Eisenberg, Fabes, \& Spinrad, 2006). This may be related to the girls' willingness to be more generous when making decisions about allocation of resources than boys. For instance, in an ultimatum game, using monetary resource, sex differences were not apparent in children younger than seven years old, but appeared in ten-year-old children. With increasing age, children become less generous but girls tend to keep their cooperative behavior. This interaction between sex and age could reflect an awareness of gender roles (Leman, Keller, Takezawa, \& Gummerum, 2009). However, many other studies did not find any sex differences in children (for a review see Eisenberg et al., 2006).

Another variable that influences cooperation is the kind of resource involved. Adults, for instance, show more tolerance for delays when rewarded with money compared to food. This is probably related to the fact that money can be stored, be converted into other reward currencies and taken on large values (Rosati, Stevens, Hare, \& Hauser, 2007). Sharing food, on the other hand, depends on who are the partners - relatives, friends, and strangers - and on the expectation of future positive interaction (Markovits et al., 2003). Moreover, food is perishable and more difficult to store.

Stickers (Benenson, Pascoe, \& Radmore, 2007; Blake \& Rand, 2010; Gummerum, Hanoch, Keller, Parsons, \& Hummel, 2010; Lucas, Wagner, \& Chow, 2008), food (Brownell, Svetlova, \& Nichols, 2009; Fehr \& Fischbacher, 2003; House et al., 2012; Markovits, Benenson, \& Kramer, 2003), and money (Gummerum, Keller, Takezawa, \& Mata, 2008; Harbaugh, Krause, \& Liday, 2003; Leman et al., 2009) have been used to investigate cooperative behavior in children, in a variety of experimental designs. However, to our knowledge only one study have recently compared the effect of different kind of resources on cooperation in 3-year-old children and have found no differences (Warneken, Lohse, Melis, \& Tomasello, 2010).

The purpose of the present study was to investigate how the kind of resource influences children's cooperation in a public goods game, and how it is modulated by sex, age and number of sessions. Typically, children and adult donations in a public goods game decrease steadily after a few rounds, independent of the age and sex of the subject and the kind of resource used (Alencar, Siqueira, 
\& Yamamoto, 2008; Burton-Chellew, Nax, \& West, 2015; Harbaugh et al., 2003; Torsvik, Molander, Tjøtta, \& Kobbeltvedt, 2011). This seems to indicate that human behavior in public goods games is inclined to be payoffbiased (Burton-Chellew et al., 2015), and that this is a universal tendency that emerges early in childhood and remains unchanged.

However, none of these studies investigated cooperation among groups of children by comparing access to different kinds of resources and accounting for sex and age differences. Hence, we decided to compare two kinds of resources, candies and stickers, because these are the most common resources used in the literature. Moreover, these two resources have different characteristics: one is perishable and difficult to accumulate, while the other may acquire a currency value. Also, we aimed to avoid any developmental differences in the understanding of currency value for tokens or money (which is not allowed by the Brazilian Ethics Committee), by choosing resources with intrinsic value. Based on previous studies, we predicted that the donations would decrease along the time, regardless of the kind of resource, and that older children would initially donate more stickers, but not candies than the younger ones. Regarding the influence of sex, we predicted no differences (Alencar et al., 2008; BurtonChellew et al., 2015; Harbaugh et al., 2003; Torsvik et al., 2011). The better understanding of the processes involved in cooperation in children is important in that it may help to improve procedures to increase children's cooperation.

\section{Method}

\section{Participants}

Participants of these studies were 131 girls and 120 boys aged five to eleven years $\left(M_{\text {girls }}=8.48, S D=\right.$ $1.37 ; M_{\text {boys }}=8.43, S D=1.35$ ) enrolled in public schools from [CITY AND COUNTRY OMITTED], which represent low socioeconomic status individuals (Akkari, 2001). Children were grouped by classroom ( $M=20.31$ children per classroom), which minimized age differences. The children had at least two months of interaction within the classroom, and no child previously attended a similar game or experiment. Interaction between children of different classrooms could occur in some of the schools, but were not frequent. Prior to the beginning of the study, the participants' parents or legal guardians gave their informed consent.

\section{Procedure}

The data from this study is part of a large dataset on children's cooperation from this laboratory. The experiment was divided into two experimental conditions, according to the type of resource, sticker condition (non-food resource) and wafer condition (food resource). Three groups were assigned to the sticker condition (58 students) and 10 groups to the wafer condition (193 students). Groups from the sticker and wafer conditions were from different schools. The participants played an iterated public goods game with eight rounds, every other day, and one round per day. The procedure in this study was the same used in Alencar et al. (2008) but for the use of stickers as a resource and the inclusion of groups with 12 or more participants only.

In each round of the experimental conditions, each participant received an apparently depersonalized envelope and three small wafers or stickers. They were instructed to go behind a screen (wood panel), where there was a box with an opening at the top, and to donate as many items as they wished to their groups. The amount of donated items was at the discretion of the children, who could decide whether to donate zero, one, two or three items. The donation should be done by putting the items inside the envelope, sealing it and depositing it inside the box. After all the children made their donations, the envelopes were opened in front of the group and discretely separated according to the amount donated. The items donated were counted and for each one, two more were added. All children were previously informed that donations would also be distributed to all participants at the end of each round, regardless of how much each child had donated or retained. The classmates did not have any information about the amount donated by each participant in the group, so donations were anonymous.

After explaining the rules of the game, the experimenter asked about the children's understanding of the rules with the following questions: "Did you understand the rules?" and "Will anybody know how much you have donated?" If children did not give the correct answers, showing that they had not yet 
understood the rules, the instructions were repeated until the rules were understood and the questions answered correctly. The teachers of each class were instructed not to make evaluative comments or suggestions and not to give any advice to children on how to behave in the game.

All students were asked to bring a pencil case or bag behind the panel in order to keep hidden any items possibly held. They were instructed to maintain the confidentiality of the values of their donations and if they had retained some items, they should hide them so that their colleagues could not see them.

The envelopes had a very small and encrypted internal marking that allowed the recognition of the child by the researchers without the child's knowledge, but maintaining the child's anonymity, while making the donations behind a screen. This marking allowed the researchers to know how many items each child donated in each round.

At the end of each round, the envelopes were removed from the box and their contents verified and counted in front of the children. Two more items were added for each item donated. The total amount was distributed equally among all participants. Thus, each child would end each round with the retained amount plus the amount they got from the distribution, being the sum named private return (Alencar et al., 2008).

The wafers were small $(7.5 \mathrm{~g})$ and the children received three of them, as well as the ones that were added by the experimenter. The stickers were around $12 \mathrm{~cm}$, with assorted designs. The stickers delivered for donation consisted of letters of the alphabet and children also received three of them. The stickers added by the experimenters consisted of images attractive to children, such as cartoon character figures and soccer team symbols. We used different stickers to motivate the children to donate. When asked in an after game interview which stickers they liked most, children varied their answer, indicating both images as well as letters stickers, suggesting that both types of stickers were attractive.

\section{Statistical Analyses}

Children were divided into two age groups: (a) younger children, aged from five to seven years; and (b) older children, aged eight to 11 years. We applied Generalized Estimating Equations (GEE) using unstructured correlation and maximum likelihood estimation. We included the following subject variables (random effects): individuals, classroom, and school. The eight rounds were considered as within-subject variable; this allowed us to monitor the effect of the previous round on the following round in the same test group. Although not every child was present in every round, it does not affect the application of GEE, as this technique allows participants with missing values to be included in the analysis. This linear model was selected to verify how private return in each round could be affected by: (a) resource type main effect (wafer or stickers); (b) sex main effect; (c) age group main effect; (d) resource type and sex interaction effect; (e) resource type and age group interaction effect; ( $f$ ) resource type, sex and age interaction effect; and ( $\mathrm{g}$ ) resource type and rounds interaction effect. We applied a customized model in which all interaction effects included resource type. In order to avoid Type I error on main and interaction effects, we apply Bonferroni correction setting the significance level to $p=.007(.050 / 7)$. Estimated marginal means and $95 \%$ confidence intervals were compared pairwise by applying sequential Sidak for multiple tests.

We computed the minimal sample size by using $\mathrm{G}^{*}$ Power a priori power analysis, considering that this is repeated measures, within-between interaction $F$ distribution model. In this power analysis, we chose moderate effect size $(f=0.25), 5 \%$ significance level, $95 \%$ power, eight groups ( 2 experimental conditions $X 2$ sexes $X 2$ age groups) and eight repeated measures (sessions), reaching a minimum sample size of 48 participants.

\section{Results}

The GEE showed that resource type significantly influenced private return. The private return mean on the sticker condition was significantly higher than private return mean on the wafer condition. Main and interaction effects are presented in Table 1. In the wafer condition, private return means significantly decreased over the rounds, while in the sticker condition they were similar up to the eighth and final round. The resource type and rounds interaction had an effect on private return showing differences between experimental conditions from the second round on (Figure 1). The type of resource and age group interaction had no effect on private return in the wafer condition. However, in the sticker condition, we observed an interaction effect on private return showing that older children had higher means when compared to younger ones (Figure 2). No resource type and sex interaction effect or resource type, sex and age interaction effect were observed. 
Table 1. Main and Interaction Effects on Private Return.

\begin{tabular}{lccc}
\hline Effect & $\chi^{2}$ de Wald & df & Sig. \\
\hline Sex & 0.16 & 1 & .685 \\
Age & 4.95 & 1 & .026 \\
Resource & 46.87 & 1 & $<.001$ \\
Sex*Resource & 6.04 & 1 & .014 \\
Age*Resource & 10.28 & 1 & .001 \\
Sex*Age*Resource & 2.18 & 2 & .337 \\
Session*Resource & 695.31 & 14 & $<.001$ \\
\hline
\end{tabular}

Bonferroni correction $p=.007$

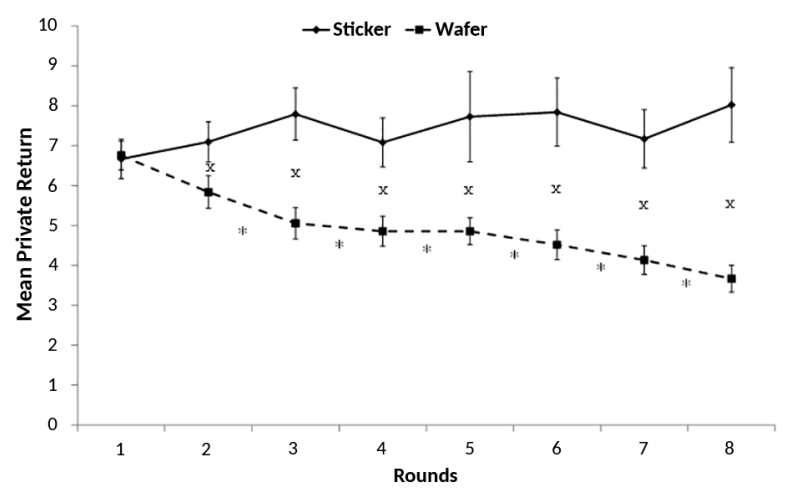

Figure 1. Mean and S.E. Private Return by Condition (Sticker And Wafer) at Each of Eight Rounds. *Statistical Difference Between Two Consecutive Rounds $(p \leq 0.05)$. ${ }^{x}$ Statistical Significance Between The Two Conditions In The Same Round $(p \leq 0.05)$.

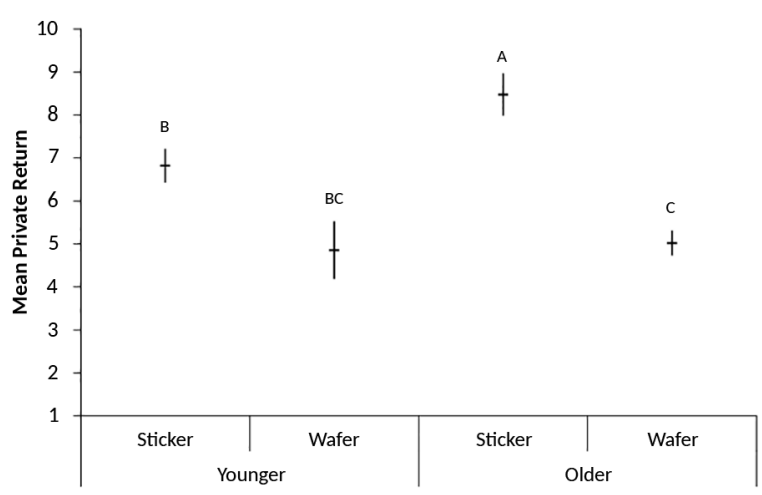

Figure 2. Mean Private Return According to Age and Kind of Resource (Sticker And Wafer). Different Letters Mean Statistical Difference Between Groups $(p \leq 0.05)$.

\section{Discussion}

In the version of the public goods game adopted in this study, all participants had initial access to the same amount of resources ( 3 items) and each could contribute with any amount from zero to three to maintain the group's resources. If all individuals donated three items of the acquired resource, the private return for each child would be equal to nine items, featuring the maximum private return to the group. Trying to maximize his/her earnings, regardless of the behavior of other players, the individual could be tempted to cheat by making his/her private return greater than that of other participants. We consider that the decisions made (to cooperate or to cheat) were not taken considering the long term benefits. Children, apparently, considered first their immediate benefits. Moreover, we have found that children's decisions differed according to their age and kind of resource, but not sex. We discuss potential explanations for these findings below.

The literature reports inconsistency on sexual differences, suggesting that boys and girls show no differences in cooperative tasks (Eisenberg et al., 2006). Accordingly, we found no sex differences in private return for the two conditions in our study. Leman et al. (2009) suggested that these differences, when present in adults, might reflect differences in gender roles. Our subjects, however, were young children and they do not have yet their gender roles well established, hence the absence of sex differences, as observed in other studies with children (Eisenberg et al., 2006).

We observed developmental differences in cooperation according to the type of resource. The younger children (5-7 years) maintained the same mean private return in both conditions, unlike older children (8-11 years), who had a larger mean private return in the sticker condition when compared to the wafer condition. This means that older children have cooperated more in the former, donating a larger amount of their resources. Hence, older children, probably, assigned different values to the resources, so they retained more wafers than stickers; whilst younger children retained as much stickers as wafers. Therefore, for older children, the type of resource can strongly affect their decision, depending on the benefits provided by the resource.

We also found that there were no differences between the private return in the first round in both those conditions, when all subjects experienced the game for the first time. From the second round on we predicted that children would donate less for the public good, regardless of the resource involved, because they could talk to each other between one session and another, and when this is allowed in a game, individuals tend to donate less in the next session (Torsvik et al., 
2011). However, over subsequent sessions it became clear that different strategies were adopted by the older children for each type of resource. From the second round, more children from both age groups decided to give less wafers, reducing the mean private return. Thus, our interpretation is that older children understood that the best strategy in the wafer condition was retention. Conversely, in the sticker condition, their means did not differ along the rounds. In this case, older children understood that the best strategy was sharing.

According to the expected utility theory, from Economics and adapted to the game theory by Von Neumann and Morgenstern (1947), individuals' decisions are made to maximize their own benefits. For this to occur in a non-zero sum game, as the public goods game, the player must know what is the strategy of the other individuals involved (Nash, 1951). The decision is also influenced by the value of the resource involved to each individual (Blake \& Rand, 2010), which is subjective and varies among players. The variability in resource values is enhanced when the resource itself is diversified, as the stickers in our experimental design.

Given that diversity, children could exchange stickers among themselves after each round. Considering that individuals are interested in increasing their personal gains in the public goods game (Burton-Chellew et al., 2015; Kümmerli et al., 2010), we suggest that older children aimed to increase their gains conditionally: quantitatively, by retaining the greatest amount of wafers; or qualitatively, by donating many stickers. Using this latter strategy, children would increase the diversity of their resources, because the stickers added to the children's donations were different from the ones they received initially. Promoted by the individual interest in the quality of new stickers, the higher donations of children in the sticker condition had as a side effect a high return to the group, creating a false perception that children were more cooperative. However, according to Burton-Chellew and West (2013), even when players are informed how much their donations would benefit other players, their decision was based on how much they would benefit from it. Probably the same thing happened in the sticker condition and players did not take their decisions based in their prosocial preferences, but, as said before, to increase their gains (Burton-Chellew et al., 2015). In the sticker condition, the best strategy to increase the gains was to donate more, which was probably understood by the older children but not by the younger ones (Burton-Chellew, Mouden \& West, 2016).
Food, on the other hand, is perishable and the ones we used were very attractive to children and did not vary in quality; they were all, both received by the children and those added to the public goods, of the same kind. Exchanging wafer by wafer did not bring any advantage, and the best strategy to optimize the benefits when there is no information about the opponents' strategy is retention, which decreases the group's return. The observed collapsing wafer donations curve along rounds is expected when an iterated public goods game is played (Fehr \& Fischbacher, 2003), no matter what resource is available. The maintenance of the sticker condition curve in high levels could be attributed to its monetary value. However, public goods game studies with adults using money resulted in the same collapsing curves (Andreoni, 1995; Burton-Chellew et al., 2015; Kümmerli et al., 2010; Torsvik et al., 2011). We therefore suggest that the key factor for the maintenance of the donations was the diversity of the stickers made available to the children, which has not been reported in other studies. We believe that older children adopted different strategies to optimize their benefits in both conditions; and these strategies, quantitative and qualitative, depend on the kind of resource used and, particularly, on their diversity.

In conclusion, different strategies may be adopted according to the quality and diversity of the resource used and the cost of cooperation may be overcome when it is more advantageous to wait for a future reward. Older children are more willing to afford the costs of cooperation because they can better understand the benefits of cooperating as well as the consequences of increasing their donations in these circumstances. We cannot, however, be sure that characteristics of the resources we used were predominant in the adoption of the different strategies, because we did not reverse the conditions (different kind of candies and same kind of stickers) to test that assumption. Future investigation could address that topic and, investigating whether food rewards, if diversified, could lead to the use of the same qualitative strategy. Further investigation is important as procedures that favor these qualitative strategies may promote cooperation in children and potentially also in adults.

\section{References}

Akkari, A. J. (2001). Desigualdades educativas estruturais no Brasil: entre estado, privatização e descentralização. Educação e Sociedade, 22(74), 163-189. doi:10.1590/s0101-73302001000100010 
Alencar, A. I., \& Yamamoto, M. E. (2008). A teoria dos jogos como metodologia de investigação científica para a cooperação na perspectiva da psicologia evolucionista. Psico, 39(4), 522-529. Retrieved from http://revistaseletronicas. pucrs.br/revistapsico/ojs/index.php/revistapsico/article/view/3786

Alencar, A. I., Siqueira, J. O., \& Yamamoto, M. E. (2008). Does group size matter? Cheating and cooperation in Brazilian school children. Evolution and Human Behavior, 29(1), 42-48. doi:10.1016/j.evoIhumbehav.2007.09.001

Andreoni, J. (1995). Cooperation in public-goods experiments: kindness or confusion? The American Economic Review, 85(4), 891-904. Retrieved from http://econweb.ucsd.edu/ jandreon/Publications/ aer1995.pdf

Benenson, J. F., Pascoe, J., \& Radmore, N. (2007). Children's altruistic behavior in the dictator game. Evolution and Human Behavior, 28(3), 168-175. http://dx.doi.org/10.1016/j.evolhumbehav.2006.10.003 doi:10.1016/j.evolhumbehav.2006.10.003

Blake, P. R., \& Rand, D. G. (2010). Currency value moderates equity preference among young children. Evolution and Human Behavior, 31(3), 210-218. doi:10.1016/j.evolhumbehav.2009.06.012

Blake, P. R., McAuliffe, K., \& Warneken, F. (2014). The developmental origins of fairness: the knowledge-behavior gap. Trends in Cognitive Sciences, 18(11), 559-561. doi: 10.1016/j.tics.2014.08.003

Brownell, C. A., Svetlova, M., \& Nichols, S. (2009). To share or not to share:When do toddlers respond to another's needs? Infancy, 14(1), 117-130. doi:10.1080/15250000802569868

Burton-Chellew, M. N., \& West, S. A. (2013). Prosocial preferences do not explain human cooperation in public-goods games. Proceedings of the National Academy of Sciences, 110(1), 216-221. doi:10.1080/15250000802569868

Burton-Chellew, M. N., El Mouden, C., \& West, S. A. (2016). Conditional cooperation and confusion in public-goods experiments. Proceedings of the National Academy of Sciences, 113(5), 1291-1296. doi: 10.1073/pnas.1509740113

Burton-Chellew, M. N., Nax, H. H., \& West, S. A. (2015). Payoff-based learning explains the decline in cooperation in public goods games. Proceedings of the Royal Society of London B: Biological Sciences, 282(1801), 20142678. doi:10.1098/rspb.2014.2678

Eisenberg, N., Fabes, R. A., \& Spinrad, T. L. (2006). Prosocial development. In N. Eisenberg, W. Damon \& R. M. Lerner (Eds.), Handbook of child Psychology (6th ed., Vol. 3, pp. 646-718). Hoboken, NJ: John Wiley \& Sons Inc.

Fehr, E., \& Fischbacher, U. (2003). The nature of human altruism. Nature, 425(6960), 785-791. doi:10.1038/nature02043

Gummerum, M., Hanoch, Y., Keller, M., Parsons, K., \& Hummel, A. (2010). Preschoolers' allocations in the dictator game: The role of moral emotions. Journal of Economic Psychology, 31(1), 25-34. doi:10.1016/j.joep.2009.09.002

Gummerum, M., Keller, M., Takezawa, M., \& Mata, J. (2008). To give or not to give: Children's and adolescents' sharing and moral negotiations in economic decision situations. Child Development, 79(3), 562-576. doi:10.1111/j.1467-8624.2008.01143.x

Harbaugh, W. T., \& Krause, K. (2000). Children's altruism in public good and dictator experiments. Economic Inquiry, 38(1), 95-109. doi:10.1111/j.1465-7295.2000.tb00006.x

Harbaugh, W. T., Krause, K., \& Liday, S. J. (2003, November). Bargaining by children (University of Oregon Economics, Working Paper No. 2002-4). doi:10.2139/ssrn.436504
House, B. R., Henrich, J., Brosnan, S. F., \& Silk, J. B. (2012). The ontogeny of human prosociality: Behavioral experiments with children aged 3 to 8. Evolution and Human Behavior, 33(4), 291-308. doi:10.1016/j. evolhumbehav.2011.10.007

Kollock, P. (1998). Social dilemmas: The anatomy of cooperation. Annual Review of Sociology, 24, 183-214. doi:10.1146/annurev.soc.24.1.183

Kümmerli, R., Burton-Chellew, M. N., Ross-Gillespie, A., \& West, S. A. (2010). Resistance to extreme strategies, rather than prosocia preferences, can explain human cooperation in public goods games. Proceedings of the National Academy of Sciences, 107(22), 1012510130. doi:10.1073/pnas.1000829107

Leman, P. J., Keller, M., Takezawa, M., \& Gummerum, M. (2009). Children's and adolescents' decisions about sharing money with others. Social Development, 18(3), 711-727. doi:10.1111/j.14679507.2008.00486.x

Lotz, S. (2014). Spontaneous giving under structural inequality: Intuition promotes cooperation in asymmetric social dilemmas. PLOS ONE 10(7), e0131562 . doi:10.1371/journal.pone.0131562

Lucas, M. M., Wagner, L., \& Chow, C. (2008). Fair game: The intuitive economics of resource exchange in four-year olds. Journal of Social, Evolutionary, and Cultural Psychology, 2(3), 74-88. doi:10.1037/ h0099353

Markovits, H., Benenson, J. F., \& Kramer, D. L. (2003). Children and adolescents' internal models of food-sharing behavior include complex evaluations of contextual factors. Child Development, 74(6), 16971708.doi:10.1046/j.1467-8624.2003.00632.x

Nash, J. (1951). Non-cooperative games. Annals of Mathematics, 54(2), 286-295. doi:10.2307/1969529

Ostrom, E. (2001). Social dilemmas and human behaviour. In R. Noë, J. A. R. A. M. Van Hooff , \& P. Hammerstein (Eds.), Economics in nature. Social dilemmas, mate choice and biological markets (pp. 23-41). Cambridge: Cambridge University Press. doi:10.1017/ CBO9780511752421.004

Rand, D. G., Arbesman, S., \& Christakis, N. A. (2011). Dynamic social networks promote cooperation in experiments with humans. Proceedings of the National Academy of Sciences, 108(48), 19193-19198. doi: $10.1073 /$ pnas. 1108243108

Rosati, A. G., Stevens, J. R., Hare, B., \& Hauser, M. D. (2007). The evolutionary origins of human patience: temporal preferences in chimpanzees, bonobos, and human adults. Current Biology, 17(19), 1663-1668. doi:10.1016/j.cub.2007.08.033

Schmidt, M. F., \& Sommerville, J. A. (2011). Fairness expectations and altruistic sharing in 15-month-old human infants. PLOS ONE, 6(10), e23223. doi:10.1371/journal.pone.0023223

Torsvik, G., Molander, A., Tjøtta, S., \& Kobbeltvedt, T. (2011). Anticipated discussion and cooperation in a social dilemma. Rationality and Society, 23(2), 199-216. doi:10.1177/1043463111404664

Vogt, S., Efferson, C., Berger, J., \& Fehr, E. (2015). Eye spots do not increase altruism in children. Evolution and Human Behavior, 36, 224-231.

Von Neumann, J., \& Morgenstern, O. (1947). Theory of games and economic behavior (2nd Rev. ed.). Princeton, NJ:Princeton University Press.

Warneken, F., Lohse, K., Melis, A. P., \& Tomasello, M. (2011). Young children share the spoils after collaboration. Psychological Science, 22(2), 267-273. doi: 10.1177/0956797610395392

Zarbatany, L., Hartmann, D. P., \& Gelfand, D. M. (1985). Why does children's generosity increase with age: Susceptibility to experimenter influence or altruism? Child Development, 56(3), 746-756. doi: $10.2307 / 1129763$ 
Phiética Raíssa Rodrigues da Silva, Mestre em Psicobiologia pela Universidade Federal do Rio Grande do Norte (UFRN), é técnica administrativa do Museu Câmara Cascudo, Universidade Federal do Rio Grande do Norte, UFRN. Endereço para correspondência: Laboratório de Estudos do Comportamento (LECH) - Departamento de Fisiologia - Campus Universitário, Universidade Federal do Rio Grande do Norte. CEP 59078-970 Natal, RN. E-mail: phiética@gmail.com

Natalia Andrea Cracciun Boccardi, Mestre em Psicobiologia pela Universidade Federal do Rio Grande do Norte (UFRN), é Doutoranda em Psicobiologia na Universidade Federal do Rio Grande do Norte (UFRN). E-mail: boccardi.natalia@gmail.com

Natalia Bezerra Dutra, Mestre em Psicobiologia pela Universidade Federal do Rio Grande do Norte (UFRN), é Doutoranda na Universidade de Durham, Inglaterra. E-mail: nbdutra@gmail.com

Wallisen Tadashi Hattori, Doutor em Psicobiologia pela Universidade Federal do Rio Grande do Norte (UFRN), Pós-Doutor Júnior (PDJ/ CNPq) pela Universidade Federal do Rio Grande do Norte (UFRN), Pós-Doutor (PNPD/CNPq) pela Universidade Federal do Rio Grande do Norte (UFRN), é Professor Adjunto A1 no Departamento de Saúde

Coletiva (DESCO) da Faculdade de Medicina (FAMED), Universidade Federal de Uberlândia (UFU). E-mail: WallHattori@gmail.com

Maria Emilia Yamamoto, Doutora em Psicobiologia pela Universidade Federal de São Paulo (UNIFESP), Pós-doutora pela University of Reading,

UK, é Professora Titular aposentada pela Universidade Federal do Rio Grande do Norte (UFRN). E-mail: emiliayamamoto@gmail.com

Anuska Irene Alencar, Doutora em Psicobiologia pela Universidade Federal do Rio Grande do Norte (UFRN), é Psicóloga da Universidade Federal do Rio Grande do Norte (UFRN). E-mail: anuskaalencar@gmail.com 